\title{
Prostate Cancer cT3a TNM Finding v7
}

National Cancer Institute

\section{Source}

National Cancer Institute. Prostate Cancer CT3a TNM Finding V7. NCI Thesaurus. Code C89219.

Prostate cancer with extracapsular extension (unilateral or bilateral). (from AJCC 7th Ed.) 